\title{
ATLAS OF \\ NEOPLASTIC \\ PULMONARY \\ DISEASE
}




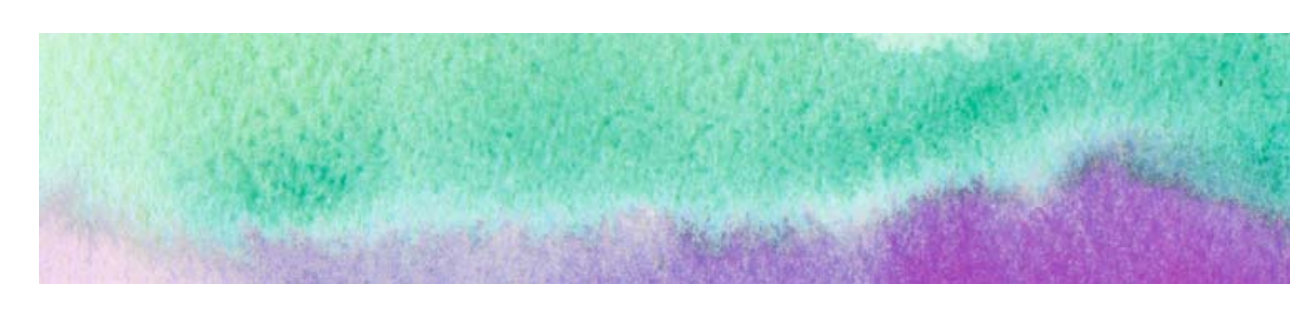

\section{ATLAS OF NEOPLASTIC PULMONARY DISEASE PATHOLOGY, CYTOLOGY, ENDOSCOPY AND RADIOLOGY}

\section{Armando E. Fraire}

University of Massachusetts Medical School, Worcester, MA, USA

\section{Philip T. Cagle}

Weill Medical College, The Methodist Hospital, Cornell University, Houston, TX, USA

\section{Richard S. Irwin}

University of Massachusetts Medical School, Worcester, MA, USA

\section{Dina R. Mody}

Weill Medical College, The Methodist Hospital, Cornell University, Houston, TX, USA

\section{Armin Ernst}

Harvard Medical School, The Beth Israel Deaconess Medical Center, Boston, MA, USA

\section{Shanda Blackmon}

The Methodist Hospital, Houston, TX, USA

\section{Timothy C. Allen}

The University of Texas Health Science Center at Tyler, Tyler, TX, USA

Megan K. Dishop

Texas Children's Hospital, Houston, TX, USA

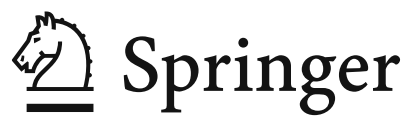




\section{Editors}

Armando E. Fraire

University of Massachusetts

Medical School

Worcester, MA, USA

Dina R. Mody

The Methodist Hospital/

Cornell University/

Weill Medical College

Houston, TX, USA

Timothy C. Allen

The University of Texas

Health Science Center at Tyler

Tyler, Texas, USA
Philip T. Cagle

The Methodist Hospital/

Cornell University/

Weill Medical College

Houston, TX, USA

Armin Ernst

The Beth Israel Deaconess Medical

Center and Harvard

Medical School

Boston, MA, USA

Megan K. Dishop

Texas Children's Hospital

Houston, TX, USA
Richard S. Irwin

University of Massachusetts

Medical School

Worcester, MA, USA

Shanda Blackmon

The Methodist Hospital

Houston, Texas, USA

ISBN 978-0-387-89838-4

e-ISBN 978-0-387-89839-1

DOI 10.1007/978-0-387-89839-1

Springer New York Dordrecht Heidelberg London

Library of Congress Control Number: 2009938107

(C) Springer Science+Business Media, LLC 2010

All rights reserved. This work may not be translated or copied in whole or in part without the written permission of the publisher (Springer Science+Business Media, LLC, 233 Spring Street, New York, NY 10013, USA), except for brief excerpts in connection with reviews or scholarly analysis. Use in connection with any form of information storage and retrieval, electronic adaptation, computer software, or by similar or dissimilar methodology now known or hereafter developed is forbidden.

The use in this publication of trade names, trademarks, service marks, and similar terms, even if they are not identified as such, is not to be taken as an expression of opinion as to whether or not they are subject to proprietary rights.

While the advice and information in this book are believed to be true and accurate at the date of going to press, neither the authors nor the editors nor the publisher can accept any legal responsibility for any errors or omissions that may be made. The publisher makes no warranty, express or implied, with respect to the material contained herein.

Printed on acid-free paper

Springer is part of Springer Science+Business Media (www.springer.com) 
To: S. Donald Greenberg, MD 


\section{PRAFACE}

The diagnosis of lung cancer and benign pulmonary tumors can be challenging. This diagnosis can be facilitated by the study of images that allow recognition of patterns of disease, both at the clinical and pathologic levels. Conceptually defined, atlases are specialized books that rely heavily upon images to illustrate any subject matter. Fitting with such a concept, this atlas was developed to fill a void in the approach to diagnosis. In contrast to previous conventional atlases, this atlas is unique in that images from four major disciplines (endoscopy, radiology, histopathology, and cytopathology) involved in the study and diagnosis of lung tumors are brought together in a single volume.

In preparing this work, we had two objectives: (1) to illustrate the common while not ignoring the esoteric by recognizing the need to cover some entities that may only infrequently cross the paths of the practitioner; and (2) to provide a quick, reliable tool that may facilitate diagnosis through recognition of images using an interdisciplinary approach. To achieve these aims, we have selected and put forward images that in our opinion best represent the tumor entities. In some instances, we have recruited the collaboration and materials from other workers in the field.

The atlas is organized into 11 parts containing 41 chapters, closely following the 2004 Classification of Lung Tumors by the World Health Organization (WHO). Accordingly, the chapters represent a wide range of neoplastic lung entities. It begins with tumors of children followed by sections on benign epithelial tumors, salivary gland tumors, mesenchymal neoplasms, lymphoproliferative disorders, cardcinoid tumors, and a section of miscellaneous tumors. The atlas further includes a chapter on WHO-recognized variants of pre-invasive lung disease, major epithelial malignancies, and concludes with a chapter on metastatic lung tumors.

We hope and believe that our efforts during the preparation of this atlas have resulted in a useful, state-of-theart work that will educate trainees and guide and support the best efforts of practitioners managing lung tumors.

Armando E.Fraire Philip T. Cagle

Richard S. Irwin Dina R. Mody Armin Ernst Shanda Blackmon Timothy C. Allen Megan K. Dishop 


\section{ACERNOWHABD GMBRNIS}

We have been fortunate to be able to benefit from archival resources within our own institutions. Many fine individuals have made significant contributions to the writing and production of this atlas and deserve special recognition and thanks. First and foremost are Ms. Karen Balcius whose expert secretarial and administrative assistance helped to coordinate the transcription and organization of the text and Mr. Luigi Piarulli, Digital Multimedia Specialist who helped us to select, process, and reproduce virtually hundreds of endoscopic, radiographic, and histopathologic and cytopathologic images. Recognition is also due to Ms. Karen Barrel and Ms. Cynthia French for their administrative assistance helping us to coordinate our busy professional lives to allow us to make room for the substantial amount of time required to put in this atlas together.

Ms. Melissa Ramondetta, Springer's Executive Editor for Clinical Medicine, and her editorial assistants, Ms. Maureen Tobin and Ms. Dianne Wuori, were a great source of help and encouragement during all phases of the production process and to them we owe a debt of gratitude. Lastly, we are deeply grateful to our many extramural colleagues who contributed images to the various chapters and to the Springer copy editors for the outstanding job they have done editing this atlas. 

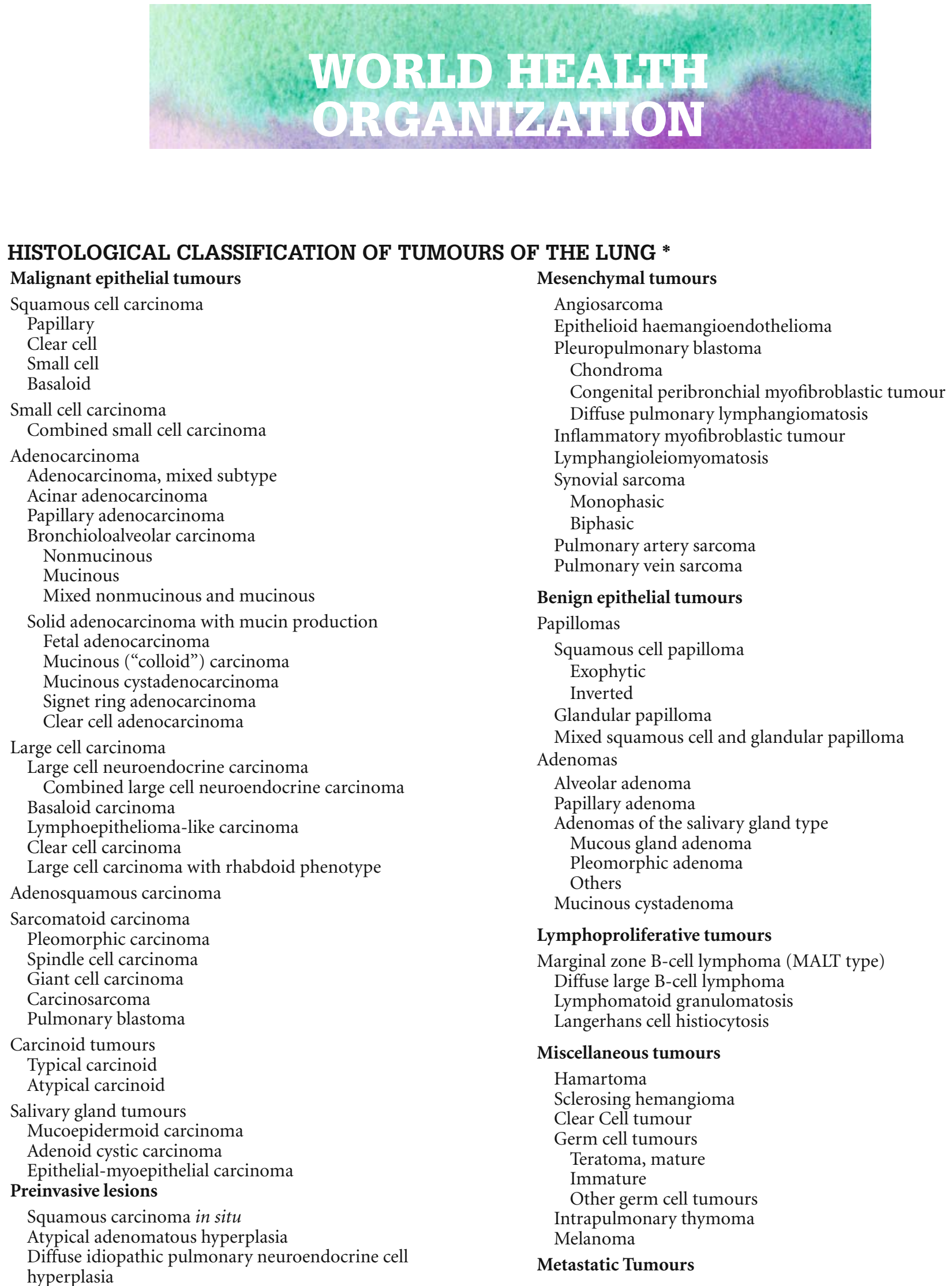

* Modified from WHO Pathology and Genetics. Tumours of the Lung, Pleura, Thymus and Heart, WD Travis, E. Brambillla, H. Konrad MüllerHermelink and CC Harris, IARC Press, Lyon, 2004 


\section{Contents}

Dedication $\mathbf{v}$

Preface vii

Acknowledgments ix

World Health Organization xi

Contributors xvii

PART I Tumors of Childhood $\ldots \ldots \ldots \ldots$. . . . . . . . . . . . . 1

Chapter 1 Lymphangiomatosis 3

Megan K. Dishop

Chapter 2 Pleuropulmonary Blastoma 7

Megan K. Dishop

Chapter 3 Congenital Pulmonary Myofibroblastic Tumor 13

Megan K. Dishop

PART II Benign Epithelial Tumors . . . . . . . . . . . . . . . . . . . . . 17

Chapter 4 Alveolar Adenoma 19

Philip T. Cagle, Timothy C. Allen, and Armando E. Fraire

Chapter 5 Uncommon Endobronchial Surface Tumors 23

Tetsu Tsukamoto, Seikan Suzuki, Armin Ernst, Toshiaki

Kawai, Yuichi Ozeki, Philip T. Cagle, Timothy C. Allen

and Armando E. Fraire

PART III Salivary Gland Tumors (Benign and Malignant) $\ldots \ldots . \ldots 31$

Chapter 6 Mucous Gland Adenoma 33

Richard S. Irwin, Philip T. Cagle, Timothy C. Allen, and Armando E. Fraire

Chapter 7 Pleomorphic Adenoma 35

Armando E. Fraire, Philip T. Cagle, and Timothy C. Allen 
Chapter 8 Mucoepidermoid Tumor 39

Shanda Blackmon, Armin Ernst, Philip T. Cagle,

Dina R. Mody and Armando E. Fraire

Chapter 9 Adenoid Cystic Carcinoma 43

Armin Ernst, Philip T. Cagle, Timothy C. Allen,

Dina R. Mody, and Armando E. Fraire

PART IV Mesenchymal Tumors (Benign and Malignant) $\ldots \ldots \ldots \ldots$

Chapter 10 Inflammatory Polyps 49

Richard S. Irwin and Armando E. Fraire

Chapter 11 Inflammatory Pseudotumor 51

Philip T. Cagle, Timothy C. Allen, and Armando E. Fraire

Chapter 12 Pulmonary Chondroma 53

Armin Ernst, Philip T. Cagle, Timothy C. Allen,

and Armando E. Fraire

Chapter 13 Pulmonary Hamartoma 55

Richard S. Irwin, Armin Ernst, Shanda Blackmon, Philip

T. Cagle, Timothy C. Allen, Dina R. Mody, and Armando E. Fraire

Chapter 14 Localized Fibrous Tumor 59

Armin Ernst, Shanda Blackmon, Toshiaki Kawai,

and Armando E. Fraire

Chapter 15 Lipomas and Liposarcomas 63

Richard S. Irwin, Ana Gimenez, and Armando E. Fraire

Chapter 16 Cystic Lymphangioma 67

Shylashree Chikkamuniyappa, Josephine Heim-Hall,

Jaishree Jagirdar, and Armando E. Fraire

Chapter 17 Lymphangioleiomyomatosis $\mathbf{6 9}$

Helmut H. Popper, Nader Morad, Issam A. Al-Bozom, Imaad Bin Mujeeb, and Armando E. Fraire

Chapter 18 Epithelioid Hemangioendothelioma 73

Toshiaki Kawai, Armin Ernst, Carol F. Farver,

Armando E. Fraire, and Anjali Saqi

Chapter 19 Pulmonary Artery Sarcoma 77

Philip T. Cagle, Timothy C. Allen, and Armando E. Fraire

Chapter 20 Synovial Sarcoma 81

Shanda Blackmon, Philip T. Cagle, Timothy C. Allen,

Dina R. Mody, and Armando E. Fraire 
Chapter 21 Marginal Zone B-Cell Lymphoma (Maltoma) 87

Shanda Blackmon, Philip T. Cagle, Timothy C. Allen,

N. Paul Ohori, Elise R. Hoff, and Armando E. Fraire

Chapter 22 Diffuse Large B-Cell Lymphoma 91

Shanda Blackmon, Armin Ernst, Philip T. Cagle,

Timothy C. Allen, N. Paul Ohori, Elise R. Hoff,

and Armando E. Fraire

Chapter 23 Lymphomatoid Granulomatosis 93

Thomas V. Colby, William G. Morice, and Armando E. Fraire

Chapter 24 Langerhans Cell Histiocytosis 97

Timothy C. Allen, Philip T. Cagle, Dina R. Mody,

and Armando E. Fraire

PART VI Carcinoid Tumors . . . . . . . . . . . . . . . . . . 101

Chapter 25 Typical and Atypical Carcinoids 103

Shanda Blackmon, Richard S. Irwin, Armin Ernst,

Philip T. Cagle, Timothy C. Allen, N. Paul Ohori,

Elise R. Hoff, Dina R. Mody, and Armando E. Fraire

PART VII Miscellaneous Tumors . . . . . . . . . . . . . . .

Chapter 26 Teratoma 109

Shanda Blackmon, Philip T. Cagle, Timothy C. Allen, and Armando E. Fraire

Chapter 27 Melanoma 111

Toshiaki Kawai, Philip T. Cagle, Timothy C. Allen, Takayuki Haga, Kuniaki Nakanishi, and Armando E. Fraire

Chapter 28 Thymoma 115

Shanda Blackmon, Richard S. Irwin, Philip T. Cagle,

Timothy C. Allen, Dina R. Mody, and Armando E. Fraire

Chapter 29 Glomus Tumor of the Lung 119

Hassan F. Nadrous and Armando E. Fraire

Chapter 30 Sclerosing Hemangioma 123

Armando E. Fraire, Giulio Rossi, Alberto Cavazza,

and Dina R. Mody

PART VIII Preinvasive Disease $\ldots \ldots \ldots \ldots \ldots \ldots \ldots \ldots \ldots \ldots$

Chapter 31 Preinvasive Disease 129

Keith M. Kerr, Dina R. Mody, and Armando E. Fraire 
PART IX Common Major Malignant Epithelial Tumors $\ldots \ldots \ldots$

Chapter 32 Squamous Cell Carcinoma 139

Shanda Blackmon, Armin Ernst, Philip T. Cagle,

Timothy C. Allen, Dina R. Mody, N. Paul Ohori, Elise R. Hoff,

and Armando E. Fraire

Chapter 33

Adenocarcinoma 145

Shanda Blackmon, Armin Ernst, Philip T. Cagle,

Timothy C. Allen, and Armando E. Fraire

Chapter $34 \quad$ Large Cell Carcinoma 151

Armin Ernst, Philip T. Cagle, Timothy C. Allen, Dina R. Mody,

and Armando E. Fraire

Chapter 35 Small Cell Carcinoma 155

Armin Ernst, Shanda Blackmon, Philip T. Cagle,

Timothy C. Allen, Dina R. Mody, and Armando E. Fraire

PART X Less Common Malignant Epithelial Tumors . . . . . . . . . . . 159

Chapter 36 Adenosquamous Carcinoma 161

Shanda Blackmon, Philip T. Cagle,

Timothy C. Allen, and Armando E. Fraire

Chapter 37 Bronchioloalveolar Carcinoma 165

Shanda Blackmon, Philip T. Cagle, Timothy C. Allen,

Dina R. Mody, and Armando E. Fraire

Chapter 38 Large Cell Neuroendocrine Carcinoma 169

Shanda Blackmon, Philip T. Cagle, Timothy C. Allen,

Dina R. Mody, and Armando E. Fraire

Chapter 39 Sarcomatoid Carcinoma 171

Shanda Blackmon, Armin Ernst, Philip T. Cagle,

Timothy C. Allen, Dina R. Mody, and Armando E. Fraire

Chapter 40 Pulmonary Blastoma 175

Shanda Blackmon, Philip T. Cagle, Timothy C. Allen,

Dina R. Mody, and Armando E. Fraire

PART XI Metastatic Tumors $\ldots \ldots \ldots \ldots$

Chapter 41 Metastatic Tumors 179

Shanda Blackmon, Armin Ernst, Dina R. Mody,

and Armando E. Fraire

Subject Index 187 


\section{CONHRIBUHORS}

Issam A. Al-Bozom, M.D. Hamad Medical Corporation, Doha, Qatar

Timothy C. Allen, M.D., J.D. The University of Texas Health Science Center at Tyler, Tyler, TX, USA

Shanda Blackmon, M.D. The Methodist Hospital, Houston, TX, USA

Philip T. Cagle, M.D. Weill Medical College, The Methodist Hospital, Cornell University, Houston, TX, USA

Alberto Cavazza, M.D. Ospedale Santa Maria Nova, Reggio Emilia, Italy

Shylashree Chikkamuniyappa, M.D. University of Texas Health Science Center at San Antonio, San Antonio, TX, USA

Thomas V. Colby, M.D. Mayo Clinic, Scottsdale, Scottsdale, AZ, USA

Megan K. Dishop, M.D. Texas Children's Hospital, Houston, TX, USA

Armin Ernst, M.D. Harvard Medical School, The Beth Israel Deaconess Medical Center, Boston, MA, USA

Carol F. Farver, M.D. The Cleveland Clinic, Cleveland, $\mathrm{OH}, \mathrm{USA}$

Armando E. Fraire, M.D. University of Massachusetts Medical School, Worcester, MA, USA

Ana Gimenez, M.D. Hospital de la Santa Creu, i Sant Pau, Barcelona, Spain

Takayuki Haga, M.D. National Highaski Saitama Hospital, Saitama, Japan

Josephine Heim-Hall, M.D. University of Texas Health Science Center at San Antonio, San Antonio, TX, USA

Elise R. Hoff, M.D. University of Pittsburgh Medical Center, Pittsburgh, PA, USA

Richard S. Irwin, M.D. University of Massachusetts Medical School, Worcester, MA, USA
Jaishree Jagirdar, M.D. University of Texas Health Science Center at San Antonio, San Antonio, TX, USA

Toshiaki Kawai, M.D. National Defense Medical College, Saitama, Japan

Keith M. Kerr, MB,ChB, FRCPath Aberdeen University Medical School, Aberdeen, Scotland, UK

Dina R. Mody, M.D. Weill Medical College, The Methodist Hospital, Cornell University, Houston, TX, USA

Nader Morad, M.D., Ph.D. University of Massachusetts Medical School, Worcester, MA, USA

William G. Morice II, M.D., Ph.D. Mayo Clinic Rochester, Rochester, MN, USA

Imaad Bin Mujeeb, M.D. Hamad Medical Corporation, Doha, Qatar

Hassan F. Nadrous, M.D. Critical Care Medicine, Knoxville, TN, USA

Kuniaki Nakanishi, M.D. National Defense Medical College, Saitama, Japan

N. Paul Ohori, M.D. University of Pittsburgh Medical Center, Pittsburgh, PA, USA

Yuichi Ozeki, M.D. National Defense Medical College, Saitama, Japan

Helmut H. Popper, M.D. University of Graz School of Medicine, Graz, Austria

Giulio Rossi, M.D. University de Modena e Reggio Emilia, Modena, Italy

Anjali Saqi, M.D. Columbia University, New York, NY, USA

Seikan Suzuki, Ph.D. Clinical Welfare College, Tokyo, Japan

Tetsu Tsukamoto, M.D. Ebetsu City Hospital, Ebetsu, Japan 